\title{
The Principle of the Presumption of INNOCENCE AND ITS CHALLENGES IN THE Ethiopian Criminal Process
}

\section{Abstract}

Simeneh Kiros Assefa, Esq.*

The administration of the criminal justice system tries to strike a balance between the search for truth and the fairness of the process. To this end, the law should protect individual rights and impose various legal burdens on the state. One such tool is the principle of the presumption of innocence until proven guilty. This is a constitutional principle under Ethiopian law and requires the public prosecutor to prove each element constituting the crime which, as argued in this article, should be proved beyond reasonable doubt. However, this principle is being violated by various subsidiary laws, procedures and practices. First, there are various provisions in the criminal law that limit (or arguably disregard) this constitutional principle. Such criminal law provisions assume as proved the existence of some of the elements of certain crimes without requiring the public prosecutor to submit evidence. Second, the Criminal Justice Administration Policy adopted in 2011 contemplates shifting the burden of proof to the defendant in selected serious crimes. Third, the courts also wrongly shift burden of proof to the accused regarding certain facts in various court decisions. These laws and judicial practices deprive the accused of the right to be presumed innocent until proven guilty. This article, inter alia, examines the constitutionality of such shifting of the burden of proof and also analyzes the standards of proof that are required in criminal cases in the Ethiopian context.

\section{Key words}

Presumption of innocence, burden of proof, criminal process, criminal justice, confessions, Ethiopia

DOI http://dx.doi.org/10.4314/mlr.v6i2.4

\section{Introduction}

The state has the primary responsibility of detection, apprehension, prosecution and conviction of offenders. In this process, the accused always faces the mighty state and this challenges the fairness of the criminal justice system. Using

\footnotetext{
* LL.B., AAU Law Faculty, 1998; LL.M., University of Pretoria, 2002; LL.M., Kyushu University, 2006; LL.M., University of San Francisco, 2008; practicing attorney before the Federal Courts of Ethiopia, member of the State Bar of California, and Lecturer at A.A.U. Law School. Contact: Simeneh@simenehlaw.com.
} 
various tools, the law tries to maintain the balance between the search for truth and ensure the fairness of the process. The criminal justice system is expected to maintain the rights of the individual even when this at times seems to go against the search for truth. The law does so by affording the individual certain protections, such as, the presumption of innocence until proven guilty before a competent, independent and impartial court and by imposing on the state the duty of proving each ingredient that constitutes the crime.

Presumption of innocence is a restatement of the rule that in criminal matters the public prosecutor has the burden of proving guilt of the accused in order for the accused to be convicted of the crime he is charged with. Burden of proof has two elements: the first element is evidentiary burden, i.e. producing evidence in support of one's allegation, while the second element relates to the burden of persuasion (also referred to as the legal burden), which is the obligation of the party to convince the court that the evidence tendered proves the party's assertion of facts. This distinction and its consequences are not appreciated in Ethiopia's legal system.

The allocation of burden of proof is complicated by factors, such as, affirmative defences and presumptions which are considered to be exceptions thereby shifting the burden of proof to the defendant. Moreover, the determination of the elements of the crime is a formidable task because often, all the elements may not be found in a single provision that defines the crime. There is also lack of clarity regarding the rules and/or the practice relating to the standards of proof.

The central issue relating to the presumption of innocence and burden of proof in Ethiopia's legal system is a matter of constitutionality. The FDRE Constitution recognises the principle of presumption of innocence and there is no exception/limitation to this principle. However, there are provisions in the Criminal Code that allow proof of facts constituting an element of a crime, mainly intention or knowledge, by presumption. In some cases, the public prosecutor does not even have to prove any basic facts for those facts to be deemed to exist. Some of the provisions even preclude contrary proof of facts that are presumed to exist. The Criminal Justice Administration Policy (the Policy) adopted by the Council of Ministers in 2011 anticipates shifting the burden of proof to the defendant in some serious crimes. Moreover, courts routinely impose the burden of proof on the defendant. These state actions and legislative provisions that shift the burden of proof to the defendant not only restrict (and sometimes nullify) the constitutional principle of presumption of innocence, but also negatively impact the fairness of the criminal justice system administration in a fundamental way.

Section 1 of the article discusses the debate in the administration of criminal justice. The themes of the discourse include how the criminal justice system should balance the detection, apprehension, prosecution and conviction of 
offenders and also ensure the rights of the suspect or accused. In so doing, it examines some of the constitutional provisions that strike a balance between the utilitarian approach to the crime control model and the process value model. It further examines the challenges posed by the subsidiary laws and the practice against such balance in value choices as enshrined in the Constitution. Section 2 highlights the concept of burden of proof, its elements, allocation of burden of proof, presumption of innocence; elements that constitute an offence that need proof and standards of proof. Section 3 dwells on whether such burden of proof on the prosecution may be shifted to the defendant by affirmative defences and presumptions. As the central theme of this article is shifting the burden of proof to the defendant by presumptions, it discusses presumptions as they exist in the law and as are contemplated in the Policy. Finally, the last section discusses burden of proof where there is alleged coercion to extort confessions during police investigation.

\section{Values Choice Debates in Criminal Justice Administration}

The criminal process is tuned at a particular point in the continuum of two extremes. On the one hand, it pursues the repression of criminal conduct by "detection, apprehension, prosecution and punishment of offenders," which is sometimes referred to as the 'crime control model;' on the other hand, it deals with the protection of the rights of the suspect in the administration of the criminal justice, which is sometimes referred to as the 'due process model'. ${ }^{1}$ It is a matter of policy of the state whether a criminal justice administration inclines in the direction of crime control or due process. Even though, such choice is certainly influenced by the political ideology of the system, the state endeavours to maintain a balance between crime control and due process in view of their interdependence. ${ }^{2}$ Thus, the law keeps a balance between the two values. ${ }^{3}$

${ }^{1}$ J. Griffiths (1970) "Ideology in Criminal Procedure or a Third 'Model' in the Criminal Process" in 79 The Yale L.J No. 3, at 363, 364, 366.

2 The political ideology of a state manifests itself by (and very much influences) the justice system, and especially in the administration of its criminal justice. A liberal and democratic society, generally, inclines toward a liberal criminal justice system administration; an authoritarian political system has an illiberal criminal process; and there are those that are in between.

${ }^{3}$ The adjective laws are addressed to officials who are "properly qualified to execute the commands of the legislature" particularly in the administration of the criminal justice. [footnotes omitted] G. J. Postema (1977) "The Principle of Utility and the Law of Procedure: Bentham's Theory of Adjudication” in 11 Georgia L. Rev., at 1398. 
Persons in public office generally tend to favour the principle of utility, and the utility of adjective law is seen only in the context of adjudication. ${ }^{4}$ The application of the principle of utility in the administration of the criminal justice aims at maximizing the correct results ${ }^{5}$ by minimizing the direct and error (moral) costs in the application of the substantive law. ${ }^{6}$ Those moral costs for the acquittal of the guilty and the conviction of the innocent are expressed in terms of low public confidence in the administration of the criminal justice. ${ }^{7}$ In order to minimize the moral cost, the criminal justice tolerates very little error; thus, the public prosecutor must prove guilt beyond a reasonable doubt. ${ }^{8}$ However, in as much as truth is an essential value, it is not an overriding value; there are what are called "process values" or "inherent process values" ${ }^{10}$ Procedures have values that are worth pursuing independent of correct outcome, although they incidentally also help achieve a correct outcome. ${ }^{11}$ Therefore, the

${ }^{4}$ The purpose of adjudication is rectitude of decision - the correct interpretation of laws and application to the facts. Therefore, the adjective law has to maximise those correct decisions. T. Anderson, D. Schum and W. Twining (2005) Analysis of Evidence, Cambridge: Cambridge University Press, at 83, 84; M. Bayles (1986) "Principles for Legal Procedure" in 5 Law and Philosophy, at 45; Postema, supra note 3, at 1397.

${ }^{5}$ Bayles, supra note 4 , at 41 . Those correct outcomes are conviction of the guilty and acquittal of the innocent.

${ }^{6}$ B. D. Underwood (1977) "The Thumb on the Scale of Justice: Burdens of Persuasion in Criminal Cases" in 86 Yale L. J., at 1307, 1330; Bayles, supra note 4, at 46, 47; Postema, supra note 3, at 1396, 97.

${ }^{7}$ Bayles, supra note 4 , at 46, 47

${ }^{8}$ Bayels, Id., at 45; Postma, supra note 3, at 1397. The 'rationalist approach' to proof in adjudication is based on three assumptions. First, it assumes litigation has its objective as the pursuit of truth through a rational process. Second, the pursuit of truth in adjudication is a high but not an overriding objective of justice. And third, pursuit of truth through reason is only a means to achieving the ends of substantive law. Anderson, Schum and Twining, supra note 4, at 79. This rationalist approach to adjudication is reflected in modern procedure and evidence laws including ours. For instance, the provisions relating to investigation and proof both in the civil and criminal procedure provisions as well as the various substantive legislations reflect the epistemological aspect of adjudication. The Constitution on the other hand contains several provisions that reflect the "process value" in the administration of the criminal justice system.

9 R. S. Summers (1974) "Evaluating and Improving Legal Process - A Plea for 'Process Values", in 60 Cornell L. Rev. No. 1, at 3.

${ }^{10}$ Bayles, supra note 4, at 51.

${ }^{11}$ Summers supra note 9, at 3, 4. Also see, Bayles, supra note 4, at 50, 51. Summers also catalogues process values some of which are: Process Legitimacy, at 21, Process Peacefulness, at 22, Humaneness and Respect for Human Dignity, at 23, Personal Privacy, at 24, Procedural Rule of Law, at 25, and Procedural Rationality, at 26. 
criminal process tries to balance the manifestation of truth (as the foundation of justice) and the process values (as expressions of fairness). This balance of values is made in the Ethiopian Constitution.

\subsection{The Constitutional Value Choice}

The law has many tools that focus on the fairness of the process independent of the correctness of outcome of the process. These tools include the principle of the presumption of innocence of the accused until proven guilty and the obligation of the state to prove each ingredient that constitutes the crime. The Constitution has fairly balanced the rule of law and the crime control models. It has clear and detailed provisions regarding the rights of the accused, the arrested or the convicted person; and this is unusual for a constitution. ${ }^{12}$

The Constitution provides that, "human rights and freedoms emanating from the nature of mankind, are inviolable and inalienable". ${ }^{13}$ Many of the constitutional rights relating to the administration of the criminal justice system emanate from the recognition of the natural rights of the person, such as, the right to life, liberty and personal security.

Although Article 17 of the Constitution deals with the right to liberty, it is also a restatement of the due process of law. It provides that "... [n]o one shall be deprived of his or her liberty except on such grounds and in accordance with such procedure as are established by law". ${ }^{14}$ [Emphasis added.] It further provides that "[n]o person may be subjected to arbitrary arrest, and no person may be detained without a charge or conviction against him". ${ }^{15}$ The Constitution also prohibits "...cruel, inhuman or degrading treatment or punishment". ${ }^{16}$ The arrested person shall not be compelled to make confessions or admissions which

Some of those process values are also discussed in one or another form by Bayles, supra note 4, at 53-56; for a similar but different perspective, see J. Thibau and L. Walker (1978) "Theories of procedure" in 66 California L. Rev., at $541-543$.

${ }^{12}$ D. A. Donovan (2002) "Leveling the Playing Field: The Judicial Duty to Protect and Enforce the Constitutional Rights of the Accused Persons Unrepresented by Counsel." 1 Eth. L. Rev., at 32, 33; Wondwossen Demissie (2000) "The Role of Courts in the Enforcement of Constitutional Rights of Suspects" Proceedings of the Symposium on the Role of Courts in the Enforcement of the Constitution. Addis Ababa: ECSC, at 45-47.

${ }^{13}$ Federal Democratic Republic of Ethiopia (FDRE) Const. Art 10(1).

${ }^{14}$ In order for a suspect to be detained, there must be a substantive law which imposes a sentence of imprisonment and there must be a procedure which provides for the manner and the requirements of arrest. In the absence of either of this, a person may not be arrested.

15 Arbitrary arrest is effected under circumstances where either of the above requirements is not met.

${ }^{16}$ FDRE Const. Art 18(1). 
would be used in evidence against him. It is further provided that, "[a]ny evidence obtained under coercion shall not be admissible". ${ }^{17}$ The arrested person has the right to be promptly informed of the reasons for his arrest (during his arrest and when he appears in court within 48 hours). ${ }^{18}$ The arrested person also has the right to remain silent and the right to be informed that any statement he makes may be used in evidence against him in court. ${ }^{19}$ The arrested person has the right to file a petition to a court for his physical release, ${ }^{20}$ and has the right to be released on bail. ${ }^{21}$

The Constitution has extensive provisions regarding the rights of the accused. The accused has the right to trial by an ordinary court of law within a reasonable time. ${ }^{22} \mathrm{He}$ has the right to be informed, in writing, of the charges with sufficient particulars. ${ }^{23}$ The accused has the right to have full access to any evidence presented against him, to examine witnesses testifying against him, to present evidence or have witnesses produced in his own defence, and to obtain the attendance of and examination of witnesses on his behalf before the court. ${ }^{24} \mathrm{He}$ has the right to be represented by a counsel and to be assisted by an interpreter. ${ }^{25}$ Another right of the accused, which constitutes the core theme of this article, is the right to be presumed innocent until proven guilty according to law. ${ }^{26}$ It is further provided that the accused may not be compelled to testify against himself. ${ }^{27}$

The Constitution is the supreme law because "[a]ny law, customary practice or a decision of an organ of a state or a public official which contravenes [the] Constitution shall be of no effect." ${ }^{28}$ The Constitution requires "[a]1l Federal and State legislative, executive and judicial organs at all levels ... to respect and enforce" the provisions relating to individual rights and freedoms. ${ }^{29} \mathrm{It}$ is evident from the readings of these provisions that the crafting and application of any

\footnotetext{
17 Id., Art 19(5).

18 Id., Art 19(1), (3).

19 Id., Art 19(2).

${ }^{20}$ Id., Art 19(4).

21 Id., Art 19(6).

22 Id., Art 20(1).

${ }^{23}$ Id., Art 20(2).

${ }^{24}$ Id., Art 20(4).

${ }^{25}$ Id., Art 20(5), (7).

${ }^{26}$ The PDR Ethiopia Constitution had similar provisions. Art 45(1) provides that "[n]o person criminally accused of violating the law shall be considered guilty unless it is so determined by a court." The Amharic version of the provision is much more closer to the provisions of the current Constitution.

${ }^{27}$ FDRE Const. Art 20(3).

${ }^{28}$ Id., Art 9(1).

${ }^{29}$ Id., Art 13(1).
} 
legislation may be made only in accordance with the Constitution. Moreover, any criminal investigation and prosecution should observe these minimum standards.

There are provisions in the Criminal Procedure Code that are meant to further the values enshrined in the Constitution. ${ }^{30}$ Regarding the due process aspect of the administration of the criminal justice, there are provisions relating to the right of the suspect or defendant to remain silent, ${ }^{31}$ to be released on bail ${ }^{32}$ protecting the suspect against unreasonable search and seizure, ${ }^{33}$ to be treated with dignity, ${ }^{34}$ to be visited by relatives and religious fathers,${ }^{35}$ to be represented by an attorney, ${ }^{36}$ to have access to and examine prosecution witnesses ${ }^{37}$ to present his defence, ${ }^{38}$ and to be presumed innocent until proved guilty by the prosecution. ${ }^{39}$ These are the inherent process values of the administration of the criminal justice.

From the crime control perspective, the Constitution embodies provisions that deal with the detection, apprehension, prosecution, and punishment of offenders in order to promote public and state security. In this regard, there are provisions that restrict the rights of the suspect or the accused. For instance, there are restrictions on the right to liberty; thus, a suspect may be arrested in accordance with the provisions of the laws of criminal procedure ${ }^{40}$ Under exceptional circumstances prescribed by law, the court may deny bail ${ }^{41}$ and keep the arrested person in custody. ${ }^{42}$ Or the court may remand the arrested person

${ }^{30}$ It is to be noted that the Criminal Procedure Code was drafted several decades before the current Constitution. However, the issue of balancing the crime control duty of the state and due process of the law is inherent in the administration of the criminal justice. Thus, there is substantial congruence between the Criminal Procedure Code enacted in 1961 and the FDRE Constitution enacted in 1994.

31 Art 27.

32 Arts 59 ff.

33 Arts $32 \& 33$.

${ }^{34}$ In effecting arrest of the suspect where there is "submission to his custody by word or action", the arresting officer may not use any force or may not even touch the body of the arrestee (Art 56(3)). During the hearing, the law prohibits chaining the defendant "unless there is a good reason to believe that he is dangerous, may be violent or may try to escape" (Art 127(2)). The law also requires that the arrestee be detained on the conditions that are prescribed for prison (Art 60).

35 Art 60.

${ }^{36}$ Art 61, 127(1).

${ }^{37}$ Art 136(2), 137.

38 Art 142.

39 Arts 141, 142.

${ }^{40}$ FDRE Const. Art 17(1).

41 Art 19(4), (6).

42 Art 19(4). 
for a time strictly required to carry out the necessary investigation, ${ }^{43}$ or demand adequate guarantees for his conditional release. ${ }^{44}$ The rights of privacy, arguably, may be restricted for the purpose of crime investigation. ${ }^{45}$ The Criminal Procedure Code is mostly in conformity with the spirit of the Constitution. Articles 11-21 deal with the initiation of investigation; and Articles 22-39 and 49-79 provide for investigation and other police activities pending investigation. Particularly relevant to the discussion, Articles 32-33 deal with search and seizure while Articles 49-59 deal with arrest and Articles 60-79 deal with bail and remand. Articles 40-48 provide for the prosecution of the suspect; and, finally, Articles 94-159 deal with the trial of the case.

\subsection{The Challenges to the Constitutional Model of the Criminal Process}

The Constitution is clear in its value choice and it balances the interests of the public and of the individual in the administration of the criminal justice. ${ }^{46}$ However, there are constant challenges to this constitutional value choice. A preliminary examination of both the laws in force and the practice in the administration of the criminal justice shows that the constitutional value choice is given a marginal place. This is because there are several procedural laws that overextend their scope and functions of crime control to the extent that they contravene the due process provisions in the Constitution. In fact, these subsidiary laws expressly provide - both in their preambles ${ }^{47}$ and in the

${ }^{43} I d$.

${ }^{44}$ FDRE Const. Art 19(4), (6).

${ }^{45} I d$., Art 26. This provision never includes a pending investigation as a ground for restriction of the right to privacy. Sub-article 3 provides that “...[n]o restrictions may be placed on the enjoyment of such rights except in compelling circumstances and in accordance with specific laws whose purposes shall be the safeguarding of national security or public peace, the prevention of crimes or the protection of health, public morality or the rights and freedoms of others."

${ }^{46}$ In the ordinary parlance there appears to be a distinction between the 'public interest' and the 'private interest;' and protection of the rights of the individual is considered a private interest. However, the protection of the constitutional rights of the individual is also a public interest in that if a state power is not constitutionally limited there is no guarantee that every member of the public will not be subjected to the arbitrary action of the state. The concepts 'public interest' and 'private interest' with apparent distinction are used here only as a matter of convenience and for clarity of ideas during these discussions.

${ }^{47}$ Unlike the practice in the common law system, the preamble is an important part of the concerned legislation in the civil law system. It is the policy justification for the adoption of the legislation; as such, it is important to understand the legislative intent in the interpretation and application of the substantive part of that legislation. 
substance of their provisions - that they aim at the crime control aspect of the duty of the state. Such are the preambles of the anti-corruption, the vagrancy control and the anti-terrorism proclamations. ${ }^{48}$

These laws modify the mainstream criminal procedure embodied in the Criminal Procedure Code, in order to meet their prime objective; i.e., suppression of crime. They modify several important procedures, such as, bail, ${ }^{49}$ remand, ${ }^{50}$ admissibility of evidence, ${ }^{51}$ etc. Many of the modifications are directed to the practice rather than the law, because there were no express provisions governing those areas where modification was sought by these laws. ${ }^{52}$ Ironically, these laws were adopted after the coming into force of the Constitution, and yet they are contrary to the Constitution. In this regard we can the standard of proof for confiscation of property for crimes of corruption, ${ }^{53}$

${ }^{48}$ The Anti-Corruption Special Procedure and Rules of Evidence Proclamation No. 236/2001, the Vagrancy Control Proclamation No. 384/2004, and the Anti-Terrorism Proclamation No 652/2009, respectively.

${ }^{49}$ Bail in the initial anti-corruption legislation was governed by the rules of the Criminal Procedure Code as there was no such provision in the Proclamation (Proc. No 236/2001). Later it was amended and the crime of corruption was made nonbailable offence (Proc. No. 239/2001, Art 2). However, it was further amended in order to make only those corruption offences that are punishable by a term of more than 10 years imprisonment non-bailable (Proc. No 434/2005, Art 4(1)). The crime of vagrancy is made non-bailable from the very beginning (Proc. No. 384/2004, Art 6(3)).

${ }^{50}$ The dangerous vagrancy law extended the period of remand form a maximum of 14 days to 28 days (Art 7). So does the Anti-Terrorism Proclamation No. 652/2009 (Art 20(3)).

${ }^{51}$ The Anti-Terrorism Proclamation contains a list of admissible evidence which would not be admissible (Art 23(1), (2) \& (4)).

${ }^{52}$ There is no evidence or procedural rule that governs the issue of hostile witness. However, the anti-corruption legislation introduces the concept of hostile witnesses and allows the prosecutor to ask leading questions during the examination in chief of its witnesses (Proc. No 236/2001, Art 40). Likewise, there is no provision in the law that exhaustively lists admissible evidence or sets forth certain standards by which admissibility could be tested. However, the anti-terrorism legislation puts in place provisions regarding the admissibility of specific evidence in such cases, (Proc. No. 652/2009, Art 23(1), (2) \& (4)). There were no express provisions that affirmatively state the standards of proof in civil and criminal matters. However, the anticorruption proclamation expressly provides for standards of proof in application for Confiscation of property acquired by corruption (Proc. No 236/2001, Arts 23 and 24).

${ }^{53}$ Confiscation of property is a penalty as provided for under the Criminal Code, Art 98. Sentence of imprisonment or confiscation of property is contingent upon proof of criminal guilt and conduct. Therefore, the crime should be proved beyond reasonable doubt before the court rules on whether defendant's property should be confiscated. 
burden of proof in corruption cases in general, ${ }^{54}$ and admissibility of specific categories of evidence. ${ }^{55}$ Even when there are provisions that conform to the values of the Constitution, the practice in the administration of justice restricts the rights of the suspect and deviates from what the law provides. ${ }^{56}$

The Criminal Justice Administration Policy adopted on March 4, 2011 by the Council of Ministers contemplates transforming the criminal justice administration. ${ }^{57}$ The Policy positively envisages the improvement of the criminal justice system. However, it has, at least, one major predicament; it tends to shift the burden of proof to the accused by the use of presumptions in a few serious crimes, such as, crimes against the Constitution and the constitutional order, acts of terrorism, crimes of corruption and organised crimes stated in the Policy. ${ }^{58} \mathrm{~A}$ brief introduction to the Policy is, thus, appropriate.

\subsection{Overview of the Criminal Justice Administration Policy}

The Policy is meant to foster efficiency, expediency and fairness in the slow and weak administration of the criminal justice system. ${ }^{59}$ The Policy introduces new

${ }^{54}$ It is argued in this article that the constitutional principle of presumption of innocence dictates that the public prosecutor has the burden of proving each ingredient constituting a crime the accused is charged with beyond a reasonable doubt; thus, an element of a crime cannot be proved by presumptions. See section 3.2 of this text.

55 The Anti-Terrorism Proclamation No 652/2009, Art 23 provides that "(1) intelligence report prepared in relation to terrorism, even if the report does not disclose the source or the method it was gathered" and "(2) hearsay or indirect evidences," among others, are admissible. These evidence are not practically subject to test by defendant; therefore, such restrictions violate the constitutional right of defendant to examine evidence presented against him as enshrined under FDRE Constitution, Art 20(4).

${ }^{56}$ See Simeneh Kiros Assefa (2010) "The Normative, Institutional and Practical Challenges in the Administration of the Criminal Justice in Ethiopia" in Ethiopian Human Rights Law Series Vol. III ; Centre for International Legal Cooperation (2005) Comprehensive Justice System Reform Program Baseline Research Report (Addis Ababa: FDRE Ministry of Capacity Building) (hereinafter 'Baseline Research Report')

${ }^{57}$ See the last paragraph of Introduction of the Criminal Justice Administration Policy ('The Policy').

58 The Policy, Section 4.6.

59 The former Federal Ministry of Capacity Building had commissioned foreign consultants to conduct a baseline research on the state of the Ethiopian criminal justice administration. The findings of the research depicts a very gloomy and sad picture of the state of the criminal justice system administration. Baseline Research Report, supra note 56. There are also other researches on the various aspects of the 
concepts and processes, such as, plea bargain ${ }^{60}$ reopening of a case after final judgment, ${ }^{61}$ prioritizing cases for investigation and prosecution, ${ }^{62}$ exclusionary rules for evidence unlawfully obtained, ${ }^{63}$ and diversion, both in terms of process and punishment. ${ }^{64}$ It has also greatly modified the investigation process both by granting broader supervision power to the public prosecutor ${ }^{65}$ and by introducing new (and arguably modern) investigation processes, such as, infiltration and secret surveillance, interception of private communication, both with or without court warrant, protection of informants and agents, and nonprosecution of a person who participated in a crime. ${ }^{66}$ The policy also addresses the longstanding problem relating to the gathering, preservation and return of exhibits $^{67}$ by granting in the matter full power to the Public Prosecutor. ${ }^{68}$

criminal justice system. See, Simeneh Kiros, supra note 56; Worku Yaze Wodage (2010) "Presumption of Innocence and the Requirement of Proof Beyond Reasonable Doubt: Reflections on Meaning, Scope and their Place under Ethiopian Law" in Ethiopian Human Rights Law Series Vol. III, Ali Mohammed Ali (2003) "The Role of Courts, Police and Prosecution in the Respect and Enforcement of Human Rights" (title in Amharic) A discussion paper presented at a workshop organised for Federal Judges, Prosecutors and Police), Menberetsehai Taddesse (2003) "Forgotten Provisions of the Criminal Justice Process" (title in Amharic) (A discussion paper presented at a workshop organised for Federal Judges, Prosecutors and Police).

60 The Policy, Section 4.5.3.

${ }^{61} I d$., Section 4.8.1.3.

${ }^{62} I d$., Section 3.14 .

${ }^{63} I d$., Section 3.16.1.

${ }^{64} I d$., Sections 4.6, 6.4.3.

${ }^{65}$ Id., Sections 3.5-3.10.

${ }^{66} I d$., Section 3.17. These methods of investigation are adopted in the Anti-Terrorism Proclamation No 652/2009. For instance, Art 14(1) provides that "in order to prevent and control terrorist acts, the National Intelligence and Security Service may,...:a) intercept or conduct surveillance on the telephone, fax, radio, internet, electronic, postal and similar communications of a person suspected of terrorism; b) enter into any premise in secret to enforce the interception; or c) install or remove instruments enabling the interception." This power is also given to the police under Sub-art (4). The police are also authorized to conduct sudden and covert searches under Arts 16 and 17, respectively. There is also authorised interception of correspondence and letters in corruption cases. Proc. No. 434/2005, Art 46.

${ }^{67}$ For in-depth examination of the problems relating to the gathering, preservation and returning of exhibits, see Mullualem Eneyew (2004) "The Gathering, Preservation and Return of Exhibits: International experience and the law and the practice in Ethiopia" (title in Amharic), a research paper presented to federal justice sector personnel Sodere: August 30- September 1.

68 The Policy, Section 3.20. 
In order to achieve these objectives, the policy anticipates capacity building of the personnel of the respective justice institutions, ${ }^{69}$ the adoption of new laws and the modification of the existing ones. ${ }^{70}$ Those laws and practices are supposed to conform to the Constitution and international human rights conventions to which Ethiopia is a party. ${ }^{71}$

One who reads those provisions would only assume that the policy anticipates improving the fairness of the criminal process. Notwithstanding this notable positive vision for the improvement of the criminal justice administration, the most serious predicament to fairness in the Policy, in relation to the theme of this article is shifting the burden of proof to the accused by providing for presumptions in serious criminal cases. Ironically, 'The Reverse Onus of Proof" is found under Part 4 titled "Improving the Effectiveness and Fairness of the Criminal Justice Process". ${ }^{72}$

\section{Burden of Proof and/or the Presumption of Innocence}

\subsection{Burden of Proof in General}

Burden of proof is the obligation of a party to a dispute to establish by evidence his assertion of facts by a required degree of certainty unless such fact is selfevident. In this proposition, there are three distinct questions: what are the elements of burden of proof? which party has the obligation to prove a given fact? and what is the quantum of evidence or the standard of proof? In addressing these three questions we will see that the concept of burden of proof is one of the most deceptively simple in theory, but elusive in terms of application. ${ }^{73}$

\subsubsection{Elements of Burden of Proof}

Burden of proof has two elements: the burden of production sometimes referred to as evidentiary burden (or onus) and the burden of persuasion sometimes

${ }^{69}$ Id., Section 3.3

${ }_{71}^{70}$ Id, Part 7; also see the legislative requirements under infra note 72.

${ }^{71} I d$, at ii

72 The last part of the Criminal Justice Administration Policy, i.e. Part 7 provides that existing legislation may be modified and new ones may be adopted to implement the Policy. Accordingly, there is a table prepared for the legislative requirements of the policy. 〈http://www.democraticdevelopment.ca/criminaljusticepolicy>

73 Sometimes burden of proof is described as 'slippery.' C. B. Mueller and L. C. Kirkpatrick (2000) Evidence under the Rules: Texts, Cases and Problems 4th Ed., (New York: Aspen Law and Business), at 767. 
referred to as legal burden (or burden). ${ }^{74}$ The burden of production is the obligation of a party to produce evidence in support of his assertion. The party who has the initial burden has the obligation to produce evidence that is "cogent" or "compelling". ${ }^{75}$ Where such party produces evidence, the other party does not have to disprove anything; however, he automatically loses if he does not produce rebuttal evidence. ${ }^{76}$ The Indian Evidence Act (IEA), from which Ethiopia's Draft Evidence Rule is borrowed, makes a distinction between the burden of production and the burden of persuasion. Thus, regarding the burden of production, Section 102 provides that " $[t]$ he burden of proof in a suit or proceeding lies on that person who would fail if no evidence at all were given on either side." Regarding the legal burden, Section 101 provides that the party desiring "any Court to give judgment as to any legal right or liability dependent on the existence of facts which he asserts, must prove that those facts exist..." In civil matters, the burden of production may be shifted to the other party by presumptions. ${ }^{77}$ In any proceedings, the party who has the legal burden or the burden of persuasion has the obligation to convince the court that the evidence (presented by either party) supports the facts he is relying on for his claim or defence. Such burden remains with the party on whom it is originally cast and cannot be shifted to the other party by any means including presumptions. ${ }^{78}$

\subsubsection{Allocation of the Burden of Proof}

Allocation of the burden of proof is allocation of risk between the parties because it is an ordinary rule of evidence that the party who has the burden of proof loses should he fail to discharge such burden. However, the party who asserts the affirmative of a fact has the burden of proof. This basic rule for allocation of the burden of proof is uniformly applied both in civil as well as criminal matters.

There are far more detailed specific provisions in civil matters for the allocation of burden of proof based on these principles, both in the substantive and procedural codes, than in criminal matters. Thus, Article 896 of the Ethiopian Civil Code that deals with claims of entitlements under a will made by a deceased provides that " $[w]$ hosoever claims rights under a will shall prove

\footnotetext{
${ }^{74}$ A. Singh (1998) Principles of the Law of Evidence 11th Ed., Central Law Publications, Allahbad, at 286; G. Dingwall (2002) "Statutory Exceptions, Burdens of Proof and the Human Rights Act 1998" Modern L. Rev., Limited, at 450, 51.

${ }^{75}$ Mueller and Kirkpatrick, supra note 73, at 769; R. C. Park, et. al., (1998) Evidence Law: A Student's Guide to the Law of Evidence as Applied in American Trials (St. Paul, Minn., West Group), at 93.

${ }^{76}$ Mueller and Kirkpatrick, Id., at 769.

${ }^{77}$ See for example FRE Rule 301, Infra note 144.

${ }^{78} \mathrm{Id}$.
} 
the existence and the contents of such will". ${ }^{79}$ Regarding a dispute on the (non)performance of a contract, the law provides that the party "who demands performance of an obligation shall prove its existence". ${ }^{80}$ Otherwise, where the other party "alleges that [such] an obligation is void, has been varied or is extinguished, [he] shall prove the facts causing such nullity, variation or extinction". ${ }^{81}$ These and similar provisions in the Civil Code and other substantive laws allocate the burden of proof in specific types of litigations. In civil litigation in general, Article 258 of the Ethiopian Civil Procedure Code provides that the plaintiff has the burden of proof.

Various issues of allocation of burden as between the litigants arise based on the above stated principles. There are different formulations of the test for the allocation of such burden. Some state that the party who needs the assistance of the court has the obligation to prove because he is the one who is challenging the status quo. ${ }^{82}$ For example, Indian Evidence Act (IEA), Section 101, first alinea, provides that the party desiring "any Court to give judgment as to any legal right or liability dependent on the existence of facts which he asserts, must prove that those facts exist". ${ }^{83}$ This test focuses on who brought the action. Accordingly, Article 258(1) of Ethiopia's Civil Procedure Code provides that “...the plaintiff shall be entitled to begin..." ${ }^{\circledR 4}$ In civil matters, It thus appears that the plaintiff bears the burden of proof. This is in conformity with the principle that the party who brought the action should prove the facts in his claim.

Almost all litigations have much more complex issues to be resolved. For the proper determination of the allocation of the burden of proof regarding each issue, there has to be another test. The better test for the allocation of the burden of proof is based on who asserts the affirmative: the party who asserts the affirmative of an issue has the burden of proof because it is much easier to prove the affirmative than the negative. ${ }^{85}$ If $\mathrm{P}$ claims that he had a contract with $\mathrm{D}$ but the latter failed to discharge his contractual obligation, $\mathrm{P}$ has to prove that there was a contract to be performed. This may be done by producing the contract

\footnotetext{
79 The manners of proof of a will are further provided for under Art 897.

${ }^{80}$ Civ. C., Art 2001(1).

${ }^{81}$ Id., Art 2001(2).

${ }^{82}$ Singh, supra note 74 , at 286.

${ }^{83}$ IEA Section 101. Second alinea further provides that, "[w]hen a person is bound to prove the existence of any fact, it is said that the burden of proof lies on that person."

${ }^{84}$ The word 'entitled' is misleading because it appears to be the right of the party to begin his case. The word is also used in Civ. P. C., Art 259(1). Seen in light of other provisions, including Arts 137(1) the Amharic version, 223(1), 256(1) and 259(1), it is not an entitlement; it is rather the duty of a party to prove a particular fact the failure of which is sanctioned by losing the litigation on that specific issues.

${ }^{85}$ Singh, supra note 74, at 285; Mueller and Kirkpatrick, supra note 73, at 768.
} 
document itself. However, this test further begs the question as to what assertion is. This rule is often misunderstood and misapplied convoluting the real problem with unrelated issues. ${ }^{86}$

Certainly, the party who alleges that a contract exists is asserting the affirmative. Assertion of the affirmative needs careful interpretation beyond its grammatical form, and it is the substance of the assertion that needs to be seen. When a person, for example, alleges the non-performance of a contract, a negative action, the proponent is also asserting the affirmative of the fact that the respondent had a positive duty and by his inaction the proponent sustained damage.

The third test which is much more specific to the burden of production of evidence but that can also at times be used for burden of proof in general is that the party who would lose the matter if evidence is not produced by either side has the burden of proof. It appears to be based on the test under Section 102 of India's Evidence Act which provides that " $t]$ he burden of proof in a suit or proceeding lies on that person who would fail if no evidence at all were given on either side." This test still does not answer all the questions regarding burden of proof; but it helps to a great extent by supplementing the previous two tests which are not significantly different from each other.

These tests for the allocation of burden of proof are applicable both in civil and in criminal matters. However, it is to be noted that in criminal matters, presumption of innocence is an important tool for the determination of the initial burden of proof. Although the constitutional principle of presumption of innocence generally allocates the burden of proof to the public prosecutor, the real allocation of the burden of proof is complicated regarding proof of each issue. Thus, when we use these tests for the allocation of the burden of proof, we have to use all of them at once, and we can allocate the burden of proof regarding a particular issue to either party only when we are positive about each test.

\subsection{Presumption of Innocence and Burden of Proof in Criminal Matters}

Presumption of innocence is not an ordinary presumption wherein the basic facts are proved and the presumed facts are taken as proved. ${ }^{87}$ Presumption of innocence is a restatement of the rule that the public prosecutor has the obligation to prove each element that constitutes the crime beyond a reasonable

\footnotetext{
${ }_{87}^{86}$ Mueller and Kirkpatrick, Id., at 767; also, see Section 4, and infra note 170.

${ }^{87}$ N. H. Holland and H. H. Chamberlin (1973) "Statutory Criminal Presumptions: Proof Beyond a Reasonable Doubt?" 7 Val. U. L. Rev. No. 2, at 147, 148; sometimes the principle of presumption of innocence is referred to as 'assumption'. Id., at 148.
} 
doubt. ${ }^{88}$ Article 20(3) of the Ethiopian Constitution stipulates that, "[d]uring proceedings, accused persons have the right to be presumed innocent until proved guilty according to law and not to be compelled to testify against themselves" ${ }^{89}$ The accused on his part is not thus required to submit proof before the public prosecutor produces evidence. ${ }^{90}$

The allocation of the initial burden of proof in criminal matters is obvious. Article 136(1) of the Criminal Procedure Code provides that "...the public prosecutor shall open his case explaining shortly the charges he proposes to prove and the nature of the evidence he will lead..." 91 This is further strengthened by the provisions of Articles 141 and 142. If, after the prosecution case is concluded, the court "finds that no case against the accused has been made out which, if unrebutted, would warrant his conviction, [it] shall record an order of acquittal". ${ }^{92}$ Conversely, where, after the prosecution evidence is concluded "the courts find that a case against the accused has been made out ... it shall call on the accused to enter upon his defence". ${ }^{93}$ In entering his defence, "[t]he accused or his advocate may then open his case and shortly explain his defence stating the evidence he proposes to put forward..." 94

Unlike other principles, there is no exception/restriction to the principle of presumption of innocence. ${ }^{95}$ There is no general restriction on the right in the

${ }^{88}$ There is no argument that exempts the state from the burden of proof. It is not only a matter of principle it is also a matter of common practice that the public prosecutor proves the charge he is marshalling against the accused. Singh, supra note 74, at 295. Further, although unstated, there is also a specific requirement that the facts need to be 'properly proved.' Properly proved means proof based on lawfully obtained, relevant, admissible and reliable evidence. Anderson, Schum and Twining, supra note 4, at 82; B. G. Joubert, S. Tarblanche and V. M. Van Rooney (1999) Criminal Procedure Handbook, Fourth Ed., (Kenwyn: Juta \& Co.), p.6.

${ }^{89}$ FDRE Const. Art 20(3)

90 Defendant is not required to participate in the proof process against himself; that is what is referred to as privilege against self-incrimination. J. D. Jackson (2005) "The Effect of Human Rights on Criminal Evidentiary Processes: Towards Convergence, Divergence or Realignment?" 68 Modern L. Rev. No. 5, at 758

${ }^{91}$ Sub-arts (2) and (3) provide for oath/affirmation and examination of prosecution witnesses which are further elaborated by the subsequent provisions, Arts 137, 139 and 140 .

92 Art 141.

93 Art 142(1).

${ }^{94}$ Art 142(2).

95 The right to life may be restricted as "punishment for a serious criminal offence determined by law" (Art 15). The right to liberty may be restricted "on such grounds and in accordance with such procedures as are established by law" (Art 17). There are also restrictions to the right to privacy as are provided for under Art 26(3). 
Constitution nor is there any specific restriction under the provisions of the FDRE Constitution. ${ }^{96}$ Therefore, in light of the foregoing discussion, the public prosecutor has the obligation to prove all the elements constituting the crime beyond a reasonable doubt in order for the accused to be convicted of such crime.

These allocations of burden of proof by the law are not arbitrary decisions; they are all in conformity with the basic principle of allocation of burden of proof discussed above - the party who asserts the affirmative shall prove the existence of such fact. Thus, in the criminal charge, the public prosecutor is asserting that the defendant has committed the crime contrary to the criminal law. Before the discussion on the issue of shifting the burden of proof to the defendant, therefore, it is appropriate to examine the facts that constitute the crime and other facts the prosecutor has to prove in his case.

\subsubsection{Elements Constituting the Crime and Other Facts that Need Proof}

Proof and the substantive criminal law are connected by the latter's identification of the elements constituting the crime. A crime is an action (or omission) that is contrary to $\mathrm{law}^{97}$ and is deemed to be completed and punishable where "all its legal, material and moral ingredients are present" ${ }^{198}$ and "where the Court has found the crime proved and deserving of punishment."

The legal element refers to the provisions of the criminal law that define whether a given action/omission is a crime. Such provisions state what facts constitute a crime the presence of which need to be proved. The identification of the elements constituting the crime is sometimes difficult and becomes a subject of heated argument in the court because all of those elements may not be provided for in the law (the relevant legal provision) that defines the crime.

Although there is no restriction on the freedom of religion, belief and opinion, there are necessary limitations on one's freedom to express or manifest his religion and belief (Art 27(5). Certainly, there are such necessary restrictions on the right of thought, opinion and expression (Art 29), and the right to assembly, demonstration and petition (Art 30).

96 Article 20(3) of the FDRE Constitution. See the discussion on possible restriction of rights provided for in the Canadian and South African constitutions under Section 3.2.1. below.

${ }^{97}$ Crim. C., Art 23(1).

98 Id., Art 23(2); Jemila Mohammed Hagos, et. al., v Public Prosecutor (Federal Supreme Court Cassation Division, Cass. F. No. 38161) Vol. 9, at 12.

99 Crim. C., Art 23(4). 
Thus, identification of the elements in such circumstances may require the judge (or the parties) to go beyond the statutory definition. ${ }^{100}$

The public prosecutor should also prove other facts that may not necessarily constitute the crime. Thus, apart from what the Criminal Code provides for, Article 111(1) of the Criminal Procedure Code provides that "[e]very charge ... shall contain: (a) the name of the accused; and (b) the offence with which the accused is charged and its legal and material ingredients; and (c) the time and place of the offence and ${ }^{101}$ where appropriate, the person against whom or the property in respect of which the offence was committed; and (d) the law and article of the law against which the offence is said to have been committed." Article 112 further provides that "[e]ach charge shall describe the offence and its circumstances so as to enable the accused to know exactly what charge he has to answer [to]. Such description shall follow as closely as [possible] the words of the law creating the offence."

The moral element of crimes is defined under Articles $57 \mathrm{ff}$ of the Criminal Code. Accordingly, a person is guilty of a crime "if, being responsible for his acts, he commits a crime either intentionally or by negligence". ${ }^{102}$ An action is not punishable "if it was performed or occurred without there being any guilt" on the part of the actor "or was caused by force majeure, or occurred by accident". ${ }^{103}$ Likewise, a person may not be convicted for "what he neither knew of or intended, nor for what goes beyond what he intended either directly or as a possibility". ${ }^{104}$

Intention exists where a person commits "an unlawful and punishable act with full knowledge and intent in order to achieve a given result"105 or that "he, being aware that his act may cause illegal and punishable consequences, commits the act regardless of such consequences may follow". ${ }^{106}$ An intentional

${ }^{100}$ Some argue that the public prosecutor has to prove that defendant committed the crime without a justification and excuse. Thus, proof of lack of affirmative defence becomes an element of a crime because it ultimately affects culpability. For instance, the court in Mullaney v. Wilbur, 343 U.S. 790 (1952) goes beyond the statutory definition of the crime of murder to find absence of passion. L. E. Chiesa (2011) "When an Offense is Not an Offense: Rethinking the Supreme Court's Reasonable Doubt Jurisprudence" 44 Creighton L. Rev., at 653, 675, 658 \& 659.

${ }^{101}$ Place and time of the crime is also provided for under Crim. C., Art 26 making the subject matter one of substance rather than mere procedure.

102 Id., Art 57(1) second alinea.

${ }^{103}$ Id., Art 57(2).

${ }^{104}$ Id., Art 58(3).

105 Id., Art 58(1)(a).

106 Id., Art 58(1)(b). 
crime, in the absence of justifications and excuses, is always punishable. ${ }^{107}$ However, once the elements constituting the crime are identified, each of them must be proved beyond a reasonable doubt by the prosecution.

Sentencing comes after conviction; thus, the facts that are essential for the determination of sentence either by aggravation, ${ }^{108}$ mitigation or otherwise are proved by preponderance of the evidence. ${ }^{109}$ This is because those facts come after the presumption of innocence is effectively disproved. ${ }^{110}$ However, where the aggravation changes the article under which the defendant is to be convicted or if it substantially increases the sentence, then those facts should be proved beyond a reasonable doubt as they relate to culpability. ${ }^{111}$

\subsubsection{Standards of Proof of Facts Constituting the Crime}

Facts exist or do not exist; they do not exist in probabilities. ${ }^{112}$ Proof of facts is assessed in terms of conviction; convictions are expressed in term of degrees which is determined based on the quantum of evidence for the determination of the ultimate fact. ${ }^{113}$ Thus, proof of facts is assessed in terms of probabilities, e.g., the occurrence of a given fact is more or less probable than its nonoccurrence where the standard of proof is by preponderance of the evidence. The "highest degree of probability" is what is called "truth". ${ }^{114}$ There is always a degree of doubt/uncertainty that is tolerated in proof because it cannot be avoided, although the degree of doubt that is tolerated in civil matters is much higher than that is tolerated in criminal matters. Therefore, it is commonly stated

${ }^{107}$ Id., Art 58(2).

108 There are two different ways of looking at the elements of the crime that are relevant to our discussion: the first is violation of what is provided for by the legislature where the law comprehensively includes all the elements of the crime. The second is violation of the prohibitive norm and the absence of justification or excuse. Thus, depending on the nature of a particular crime, the public prosecutor has the burden of proving both the commission of a crime and where appropriate, the absence of justification or excuse. Chiesa, supra note 100, at 650, 651 .

109 Id., at 654, 657, 666.

${ }^{110} \mathrm{Id}$., at 654 .

${ }^{111}$ Chiesa, supra note 100, at 649, 650.

112 G. Postema (1983) "Fact, Fiction and the Law: Bentham on the Foundation of Evidence" in William Twining (ed.), Facts in Law 16 Archiv fur Rechts-und Sozialphilosophie, at 40.

113 Id., at 41, 42 \& 57; Park, et. al., supra note 75, at 88.

${ }^{114}$ Per Olof Ekelof (1964), "Free Evaluation of Evidence" in 8 Scandinavian Studies in Law, at 51. Also see Postema, supra note 112, at 39, 44 
that the prosecution has to prove its case beyond a reasonable doubt in order for the defendant to be convicted. ${ }^{115}$

According to the American common law understanding of standards of proof, there are three levels of proof. ${ }^{116}$ Proof in civil matters are not that strict; the most lenient degree of proof is by the preponderance of the evidence. In selected matters, where for policy reasons the legislature chooses a higher standard of proof, clear and convincing evidence is required. We seem to have these common law types of standards of proof. The standards of proof in judicial decisions is nowhere expressly stated in Ethiopia's laws except in the Revised Anti-Corruption Special Procedure and Rules of Evidence regarding confiscation of property obtained as a result of corruption. ${ }^{117} \mathrm{~A}$ closer examination of the matter gives the impression that in such areas where there is no specific type of evidence required, as suggested by the Revised AntiCorruption Special Procedure and Rules of Evidence Proclamation No.434/2005, a lesser standard of proof by preponderance of the evidence is good enough.

In some instances, although the law does not specifically refer to the degree of proof, the substantive codes provide for specific modalities of proof. e.g., proof of ownership, ${ }^{118}$ proof of a will, ${ }^{119}$ and proof of filiation. ${ }^{120}$ Those types of evidence, by their very nature, have higher probative value and thus proof by such evidence is stricter than proof by preponderance of the evidence. The standard of proof in those instances can properly be referred to as clear and convincing evidence.

${ }^{115}$ In the United States the rule is established by the Supreme Court in re Winship 397 U.S. 358 (1970). See further, Chiesa, supra note 100, at 649. In the United Kingdom and its former colonies, including India, the allocation of the burden of proof is established by the House of Lords in Woolmington v. Director of Public Prosecution (1935) A.C. 462.

${ }^{116}$ K. M. Clermont and E. Sherwin (2002) "A Comparative View of Standards of Proof" 50 Am. J. Comp. L., at 251-53. In the British system, however, there are only two standards of proof: proof by a balance of probabilities for civil matters and proof beyond a reasonable doubt in criminal matters.

${ }^{117}$ Revised Anti-Corruption Special Procedure and Rules of Evidence Proclamation No.434/2005, Art 33 provides that " $[\mathrm{t}]$ he standard of proof required to determine any question arising as to whether a person has benefited from criminal conduct, or the amount to be recovered shall be that applicable in civil proceedings" This provision was initially introduced in Proc. No 231/2001, Art 24.

118 Civ. C., Arts 1193 - 1203.

119 Id., Arts 896, 897.

${ }^{120}$ Fam. C., Arts 123 ff. 
The standard of proof required in criminal matters is different from that required in civil matters. All the elements constituting the offence have to be proved beyond a reasonable doubt in order to find the defendant guilty. ${ }^{121}$ Proof beyond a reasonable doubt is a common law concept. ${ }^{122}$ The concept of 'a reasonable doubt' is nowhere intelligibly defined thus leaving the concept vague. ${ }^{123}$ The standard of proof in criminal matters is not established in our laws nor is it stated in the Federal Supreme Court Cassation Division decisions that are binding interpretation of the law. However, there are indications that the standard of proof in criminal matters is much higher than in civil matters. ${ }^{124}$ The courts in Ethiopia were applying the "beyond a reasonable doubt" standard of

${ }^{121}$ The standards of proving the elements of the crime is not uniform when such element of the crime is proved as an offence, as a defence or as an affirmative defence. The rule is all the elements constituting the crime have to be proved beyond reasonable doubt in order for a defendant to be convicted of such crime. However, when a defendant raises it as a defence, he has to prove such fact by preponderance of the evidence in order to create reasonable doubt. Where the fact is raised as an affirmative defence, defendant has to prove that fact by preponderance of the evidence and the public prosecutor has to disprove it beyond a reasonable doubt. For in-depth analysis of the subject, see Chiesa, supra note 100. Also see infra note 140.

${ }^{122}$ In the United States, for instance, although the concept of proof beyond a reasonable doubt has long standing history, it is crystallized in re: Winship and elevated to the level of a constitutional rule relatively recently. Underwood, supra note 6, at 1301; J. C. Sheldon, "Presumptions against Criminal Defendants, Affirmative Defenses, and a Substantive Due Process Interpretation of County Court of Ulster v. Allen" 34 Maine L. Rev., at 306; Chiesa, supra note 100, at 649; Mueller and Kirkpatrick, supra note 73, at 801 . The concept is reaffirmed by Mullaney v. Wilbur 343 U.S. 790 (1952) and Patterson v. New York 432 U.S. 197 (1977).

${ }^{123}$ See in general, R. D. Bartels (1981) "Punishment and the Burden of Proof in Criminal Cases: A Modest Proposal" 66 Iowa L. Rev.; Underwood, supra note 6, and Chiesa, supra note 100.

${ }^{124}$ Article 2149 of the Civil Code regarding tort claims resulting from a criminal action where a criminal case is filed in another court provides that "[i]n deciding whether an offence has been committed, the court shall not be bound by an acquittal or discharge by a criminal court." Likewise, where there is a civil claim joined to a criminal action, Article 158 of the Criminal Procedure Code stipulates that "[w]here the accused is acquitted or discharged, the court shall not adjudicate on the question of compensation and shall inform the injured party that he may file a claim against the accused in the civil court having jurisdiction." These provisions do not directly state the standard of proof that is employed in civil and criminal trials; however, they give indications that the standard of proof in criminal matters is higher than that required in civil matters. The fact that the Civil Code is borrowed from the continental system and the Criminal Procedure Code is borrowed from the common law system indicates that the difference in the standards of proof in civil and criminal matters is universal. 
proof in criminal matters which was presumably introduced by British judges and government advisors. ${ }^{125}$ It appears that the proof beyond a reasonable doubt principle has been taken to heart, and our judges were consistently using the words when they enter judgment whether it is acquittal or conviction of defendant. $^{126}$

In the French system, including Germany, representatives of the civil law system, the degree of proof required to convict a defendant is "thorough conviction" or conviction intime of the judge. This standard does not prescribe rules that can be cited as a source on which "the fullness and sufficiency of a proof particularly depend" but rather requires of the judges "that they ask themselves, in silence and reflection to seek out, in the sincerity of their conscience, what impression the evidence reported against the accused and the ground of his defense have made on their reason". ${ }^{127}$

${ }^{125}$ Buhagiar, a Maltese, and a British citizen was president of the High Court here in Ethiopia. His mentor and the one who brought him to Ethiopia, Sir Charles Matthew, also British and previously Chief Justice in Malta, was Ethiopian Government advisor at the Ministry of Justice since the second half of the 1950s. Trained and having had worked in the common law system, it is presumed that they introduced the principle of proof beyond a reasonable doubt standard of proof. Buhagiar, William <www.maltamigration.com> (last accessed 26 August 2009).

${ }^{126}$ In recent years, there are judgments which state that that the defendant "has (not) disproved the prosecution evidence." This effectively eliminates the meaning of "a reasonable doubt." It is not clear whether the judges use this phrase in their ruling either because of gaps in reasoning and poor evaluation of the evidence or indifference to the concepts of a reasonable doubt and the degree of proof that is expected of the defendant. At times, court records show that the judge does not even properly evaluate the prosecution evidence when entering a ruling based on Article 141 of the Criminal Procedure Code. In some recent decisions there is no mention of (beyond) a reasonable doubt in writing judgment. There is not even consistent use of the phrase "beyond a reasonable doubt." There are all sorts of phrases for the concept. Worku Yaze, supra note 59, at 133, 134 note 37.

127 Article 353 of the French Code of Criminal Procedure provides the following:

"[b]efore an assize court [the court trying felony cases] retires, the president shall read the following instructions, which, in addition, shall be posted on large letters in the most prominent place in the conference room:

The law does not ask an accounting from judges of grounds by which they became convinced; it does not prescribe for them rules on which they must make the fullness and sufficiency of a proof particularly depend; it requires of them that they ask themselves, in silence and reflection to seek out, in the sincerity of their conscience, what impression the evidence reported against the accused and the ground of his defense have made on their reason. The law asks them only the single question, which encompasses the full measure of their duties: 'Are you thoroughly convinced?'” 
A certain degree of proof is required only to create an equivalent degree of moral certainty in order to reach a certain conclusion regarding a material fact. The degree of one's conviction or moral certainty cannot be measured. The lack of such measurement, makes a rational discussion almost impossible on whether a common law jury is better convinced when a fact is proved beyond a reasonable doubt or a civil law judge is better convinced when the facts are proved to conviction intime of the judge. It is certain that both concepts of standards of proof serve the respective society and it is believed that both have achieved their respective purposes. ${ }^{128}$ It is cogently argued by comparative lawyers that in criminal matters, the civil law conviction intime and the common law beyond a reasonable doubt standards of proof are equivalent. ${ }^{129}$

Although there are no proper and rational distinctions to be made between the common law concept of beyond a reasonable doubt and the civil system concept of conviction intime, regarding the degree of conviction in the mind of the trier of fact, our courts need to continue using the common law 'beyond a reasonable doubt' standard of proof in criminal matters for the following reasons. ${ }^{130}$ First, Ethiopian courts have been using beyond a reasonable doubt standard of proof for a long time and all practitioners appear to have taken it as the norm thereby rendering its continued use much easier than the civil law conviction intime. Second, beyond a reasonable doubt standard of proof appears to be much more intelligible than the conviction intime because it is seen in the context of the other two standards of proof - preponderance of the evidence and clear and convincing evidence. Third, related to the foregoing two reasons, beyond a reasonable doubt standard of proof is much less susceptible to abuse than conviction intime. Fourth, both the Criminal Procedure and the Civil Procedure Codes are borrowed from the adversarial systems, and the use of beyond a reasonable doubt standard of proof is only a matter of consistency. Finally, the general background of the working situation of the two standards of proof, the training of the judges in the respective systems and integration of the work of the police and the prosecution office is different in systems that have

Also see, in general, Clermont and Sherwin, supra note 116.

${ }^{128}$ Different legal traditions may have different processes. However, human rights conventions and procedures have the effect that the systems have a more or less common standard of process across legal systems. Jackson, supra note 90, at 739.

129 Clermont and Sherwin, supra note 116, at 245, 246.

${ }^{130}$ A proper and serious comparative examination of both concepts indicates that there is no distinction between the common law beyond a reasonable doubt standard and the civil law conviction intime. The unifying factor is the individual right to presumption of innocence until proven guilty which requires a higher standard of proof. Although the concept has not brought about convergence of the two systems' procedures of proof neither system's fair process is superior to the other. Jackson, supra note 90, at 757, 764; Clermont and Sherwin, supra note 116, at 245, 246 
beyond a reasonable doubt standard of proof and those that have conviction intime. In this regard, the administration of our criminal justice is much tuned to the common law system, and our judges have yet to have suitable training and a different working experience to handle conviction intime and make a proper distinction between conviction intime in civil and criminal matters. ${ }^{131}$

Thus, the public prosecutor in Ethiopia has to prove all the elements constituting the crime beyond a reasonable doubt. Elements of the crime include not only the violation of the law prohibiting the act or omission, but it may also include absence of justification or excuse. ${ }^{132}$ Further, where the fact is an aggravating circumstance constituting an element of the crime, it has to be proved beyond a reasonable doubt. ${ }^{133}$ Such is the case where, because of aggravation, the provision under which the accused is to be convicted is changed even though he is not originally charged under that Article.

\section{Burden of Proof Borne by the Defendant}

\subsection{Affirmative Defences}

The initial burden of proof that the state bears to prove all the ingredients of a crime beyond reasonable doubt (in order for defendant to be convicted) may appear to be shifted to the defendant only in two circumstances. They are where the defendant raises affirmative defences and where the law allows an ingredient of a crime to be proved by presumptions. Although the main focus of this article is presumptions, a few words may be appropriate about affirmative defences, a tool by which the burden of proof is said to be shifted to the defendant. ${ }^{134}$

In the General Part of the Criminal Code, there are justifications and excuses which may fully or partly exempt defendant from criminal liability. ${ }^{135}$ When a defendant raises any of these affirmative defences, he is not denying the facts; the defendant rather affirms the action or omission asserted by the prosecution,

131 In the civil law system, both in France and Germany, the standard of proof required in civil matters and criminal matters is conviction intime. Clermont and Sherwin, Id., at 245-47, 250. It is alluded earlier that the standards of civil and criminal matters is different. Thus, while using the same standard, making different application is quite a task.

132 G. C. Christie and A. K. Pye (1970) "Presumptions and Assumptions in Criminal Law: Another View" Duke L. J., at 935, 936).

133 Chiesa, supra note 100, at 654.

${ }^{134}$ Some even consider shifting both elements of burden of proof amount to affirmative defences. Sheldon, supra note 122, at 291, 292.

135 Some of the justifications and excuses include, absolute coercion (Art 71), superior order (Art 73), necessity (Art 75), legitimate defence (Art 78) and mistake of fact (Art 80). 
but invokes justifications or excuses against criminal liability. This involves alleging the presence of other facts that do not form part of the prosecution's assertions. In affirmative defences, because the defendant is asserting new facts, the burden of proving those new facts is on him. This is perfectly in line with the principles discussed above for allocation of the burden of proof as between the litigants. ${ }^{136}$ A defendant, however, by his affirmation of the facts alleged by the public prosecutor, waives the burden of proof borne by the public prosecutor regarding the facts constituting the crime. Affirmative defences do not actually shift the burden of proof because they do not constitute exceptions to the prosecutor's duty to prove guilt beyond a reasonable doubt. ${ }^{137}$

Some legal systems have the rule that defendants have to prove justifications or excuses by the preponderance of the evidence while the public prosecutor may disprove such justification or excuse beyond reasonable doubt. ${ }^{138}$ This is not, however, compatible with Ethiopia's laws. Nevertheless, as guilt (as discussed in the preceding section) must be proved by the public prosecutor beyond a reasonable doubt for a criminal conviction, it is sufficient for defendant to create a reasonable doubt on the prosecution's case.

\subsection{Presumptions}

Presumptions are not rules of evidence; they are procedural rules that define the relationship between two facts - the basic facts and the presumed fact. ${ }^{139}$ The relationship is that, a presumed fact is deemed proved until proven otherwise by the other party if the party in whose favour the presumption operates proves the basic facts by a required degree. The degree of this relationship between those facts differs in different circumstances. The minimum requirement is that there has to be a rational/logical relationship between the basic facts and the presumed facts. ${ }^{140}$ For instance, in the case of the issue of paternity, where a man lives

${ }^{136}$ See the discussion on the allocation of burden of proof 2.1.1 above. Also see Underwood, supra note 6, at 1303, 04 including note 11 thereunder.

137 IEA, Sec 105.

${ }^{138}$ This is the case in the United States, for example. Chiesa, supra note 100, at 657.

139 P. C. Giannelli (2003), Understanding Evidence (New York: Matthew Bender and Co.), at 54

${ }^{140}$ Regarding presumptions in civil matters, it is necessary to see if there is a rational connection between the operative facts and the presumed facts, and whether the connection is good enough. See Mobile, Jackson \& Kansas City R. R. Co. v. Turnipseed 219 U.S. 35 (1910) (Holland and Chamberlin, n 88 above, at 162). The degree of the relationship between the basic facts and the presumed facts range from a rational one, when it is permissive presumption, to one of beyond a reasonable doubt, in mandatory criminal presumptions. Sheldon, supra note 122, at 279, 283,284 . When the mandatory statutory presumptions were initially introduced, the requirement was that there be a rational connection between the operative facts and 
with a woman in wedlock and a child is born after 180th day after the marriage and before the 300th day after divorce, the paternity of the man is presumed. ${ }^{141}$ There is a logical connection between the facts of the man's living with the woman in wedlock for a specified time and the issue of paternity to a child born during the marriage. Likewise, where there is a house rental agreement in which "A" pays a sum of money to "B" on a monthly basis, a receipt issued by "B" for the month of September leads to the presumption that the payments for the prior months are paid. ${ }^{142}$ There is certainly a rational connection between the receipt for the month of September and the issue of payment for the previous months because they are similar transactions emanating from the same legal obligation.

There are two types of presumptions: rebuttable and irrebuttable presumptions. In rebuttable presumptions, once the party in whose favour the presumption operates proves the basic facts, the other party may produce evidence in order to disprove such presumption. The effect of (rebuttable) presumption is that, it shifts the burden of proof to the other party against whom such presumption operates. However, it is only the burden of production that is shifted. In the common law system, where evidence on the issue has not been produced, such non-production of evidence generally exposes a party to an adverse result or a directed verdict. ${ }^{143}$ The burden of persuasion remains with the party on whom it is originally cast. ${ }^{144}$

the presumed fact. However, when such presumption affects presumption of innocence such relationship is required to be one of beyond a reasonable doubt. Christie and Pye, supra note 132, at 923, 924. For the progressive modification of this standard by the U.S. Supreme Court, see Holland and Chamberlin, supra note 87, at $154-159$.

141 Fam. C., Arts 126, 128.

142 Civ. C., Art 2022.

${ }^{143}$ Directed verdict is a verdict by the judge on matters of fact without presenting the issue of facts to the jury. As Ethiopia does not have a jury system there is no directed verdict. However, the decision to be entered as per Civ. Pro. C., Art 256 is equivalent to this concept of directed verdict. It provides that "[w]here evidence which should have been produced in accordance with Art. 137 or 249 is not so produced due to the default of either party, the court may at once pronounce judgment ..."

${ }^{144}$ Regarding presumption in civil actions and proceedings, U.S. Federal Rule of Evidence (FRE) Rule 301 provides that "[i]n all civil actions and proceedings not otherwise provided for by Act of Congress or by these rules, a presumption imposes on the other party against whom it is directed the burden of going forward with evidence to rebut or meet the presumption, but does not shift to such part the burden of proof in the sense of the risk of non-persuasion, which remains throughout the trial upon the party on whom it was originally cast." Also, see G. Weissenberger 
In irrebuttable presumption, once the presumption is established the other party is precluded from disproving such presumption. Such rules are not in the realm of evidence law; they are rules of substantive law. ${ }^{145}$ There are social policy justifications for the application of presumptions, both rebuttable and irrebuttable, in civil matters. ${ }^{146}$ There appears to be limited application of rebuttable presumptions in criminal matters; however, to the knowledge of this author, there is no irrebuttable presumption that operates in criminal matters in any other legal system.

\subsubsection{Presumptions in Criminal Matters}

It is an essential manifestation of the principle of presumption of innocence that the state has to prove all the elements constituting the offense beyond a reasonable doubt in order for defendant to be convicted. ${ }^{147}$ In several legal systems, there is no exception to this principle. For instance, in Re Winship ${ }^{148}$ the U.S. Supreme Court held that the public prosecutor has to prove all the ingredients constituting the crime beyond a reasonable doubt. It appears there is no meaningful exception to this rule. In criminal matters, the U.S. Supreme

(1995) FEDERAL EVIDENCE: 1996 Courtroom Manual (Cincinnati: Anderson Publishing Co.) at 29.

145 Giannelli, supra note 139 , at 53.

146 Those policy justifications in using presumptions for proof of facts in civil matters may be seen in the area of presumption of absence, presumption of paternity and presumption of payment. They are all designed to address social problems to make life easy for those affected by the event. The application of such presumption is between the parties which are deemed to have equality of arms and the effect, if there is such negative effect, is only on the property rights or status of the parties.

${ }^{147}$ When a fact is to be proved, it has to be proved in any of the modalities of proof; customarily, there are oral evidence (testimony), documentary evidence and exhibits. Presumptions, although referred to as modalities of proof under Civ. C., Arts 2002 and 2003, in their application in criminal matters, presumptions are exemptions of proof. Proof is an affirmative showing of the existence or inexistence of a fact. Furthermore, presumptions are different from inferences in that they are legislative decisions of mandatory inferences; inferences are left to the discretion of the judge to make his own findings based on his experience and knowledge regarding the relationship between the different categories of facts.

${ }^{148}$ Beyond a reasonable doubt standard of proof is not a constitutional principle; however, the presumption of innocence is crystallized in and is elevated to a constitutional right level in Re Winship by the U.S. Supreme Court. See supra note 122. Thus, if presumption of innocence is given a constitutional stature, it follows that the other side of the subject, a reasonable doubt, should also be afforded equal treatment because the two are inseparably intertwined. Holland and Chamberlin, supra note 87 , at 149 . 
Court held that only permissive statutory presumptions are constitutional. ${ }^{149}$ Where there is mandatory statutory presumption, the prosecutor must "demonstrate beyond a reasonable doubt that the presumed fact may be inferred from the proved fact or facts" 150 thereby rendering them useless to the prosecution. Thus, the prosecution cannot rely merely on the inference as a "sole and sufficient basis for finding" of the presumed fact; it must also be shown that such inference actually works "as a matter of objective fact". 151

In few legal systems, presumption of the existence of an element constituting a crime is considered to be an exception to the above stated rule. For instance, in the United Kingdom, in Woolmington v Director of Public Prosecutions it is held that statutory provisions that shift burden of proof to the defendant by presumption are to be regarded as exceptions to this rule. ${ }^{152}$ Such parliamentary acts authorising proof of elements constituting the crime by presumption are usually related to intention or knowledge. The validity of such legislation is tested based on the 1998 Human Rights Act (which is adopted in order to enable the UK discharge its treaty obligations) and Article 6(2) of the European Convention on Human Rights (ECHR) which provides that "[e]veryone charged with a criminal offence shall be presumed innocent until proved guilty according to law."

The 1971 Misuse of Drug Act does not require the Prosecution Services to prove knowledge of the content of the substance in order to prove possession if a defendant was proved to be in control of such substance; it rather places the burden on the defendant to prove that he does not have such knowledge of the content of the substance. ${ }^{153}$ The validity of the manner of proof of knowledge in this legislation was tested against UK's treaty obligation under ECHR. Although the provisions of Article 6(2) are stated in absolute terms, the European Human Rights Court's jurisprudence (Salabiaku v France) indicates that, it does not

${ }^{149}$ Holland and Chamberlin, Id., at 153.

150 The U.S. Supreme Court in the Ulster case severely restricted the application of mandatory presumptions that it made it "practically useless to the prosecution." Sheldon, supra note 122, at 278, 279, 287, 288

${ }^{151} I d$., at 278, 279, 287, 288. Statutory criminal presumption some opine, must be regarded as 'irrational' or 'arbitrary' ...if there is a reasonable doubt as to the inference of the presumed fact from proof of the operative facts on which it is made to depend. Holland and Chamberlin, supra note 87 , at 166 . When prosecution is proving a fact by presumption, the presumed fact should not receive less evidentiary treatment than other facts constituting the crime. $I d$., at 163. Statutory presumptions are manifestations that the legislature has less concern for reasonable doubt standard and presumption of innocence. Ibid, at 151 .

152 (1935) A.C. 462; Dingwall, supra note 74, at 450.

153 Id., at 457. 
prohibit presumption of law or fact. It only "requires states to confine them[selves] within reasonable limits which take into account the importance of what is at stake and maintain the rights of the defence". ${ }^{154}$ Therefore, the House of Lords held that the convention does not prohibit shifting the legal or evidential burden to the accused. ${ }^{155}$

The court, however, made a distinction between the legal burden and the evidential burden. Shifting the evidentiary burden to the defendant is held to be not contrary to UK's treaty obligation. Regarding the legal burden, the court adopted two stages of analysis: validity of government objective and proportionality of the measure. It was held by majority that imposing the legal burden on the defendant is a disproportionate response to any public objective. ${ }^{156}$

Likewise, Article 11(d) of the Canada Charter of Rights and Freedom provides for presumption of innocence. The provisions of Article 1 make it clear that this right is subjected to "... such reasonable limits prescribed by law as can be demonstrably justified in a free and democratic society." Under the Drug Control Act, which is substantially identical to the UK's 1971 Misuse of Drug Act, David Edwin Oakes was charged with possession of hashish oil for the purposes of trafficking. He was found in possession (control) of the substance with the presumed knowledge of the content of the substance. The accused challenged Section 8 of the Narcotic Control Act on the basis that it violated Article 11(d) of the Charter. The Supreme Court of Canada adopted the test whether there is "pressing and substantial" government objective to warrant overriding a constitutionally protected right that may be upheld under Article 11 of the Charter; and if so, whether the means (shifting the burden of proof to defendant) is proper. The Court finally struck down the rule on the ground that it violates defendant's right to presumption of innocence. ${ }^{157}$

The South African Constitution, very much influenced by the Canadian Charter, has detailed provisions regarding the limitation of the rights enshrined in the Constitution. Thus, Section 36 (1) provides:

[t]he rights in the Bill of Rights may be limited only in terms of law of general application to the extent that the limitation is reasonable and justifiable in an open and democratic society based on human dignity, equality and freedom, taking into account all relevant factors, including-

a) the nature of the rights;

b) the importance of the purpose of the limitation;

c) the nature and extent of the limitation;

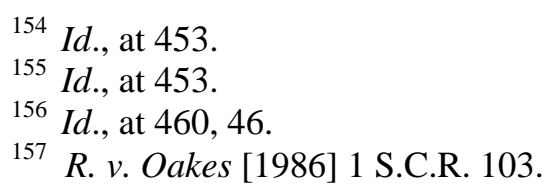


d) the relation between the limitation and its purpose; and

e) less restrictive means to achieve the purpose. ${ }^{158}$

Such shifting of the burden of proof to defendant may be constitutional for systems like the UK where acts of parliament are not subsidiary to a written constitution ${ }^{159}$ or South Africa and Canada where there is a constitutional provision for limited authorisation of restriction of rights within the bounds of such authorisation.

Ethiopia has, however, adopted a constitution which incorporates and entrenches the principle of the presumption of innocence of the accused until proven guilty before an independent, competent and impartial court. As discussed above, the Criminal and the Procedure Codes require that 'intention' as an element of a crime needs to be proved separately as a fact constituting an element of such crime. ${ }^{160}$ Despite such constitutional provisions, however, Ethiopia has adopted laws which provide for proof of intention or knowledge by presumption in several and diverse types of crimes.

There is even an irrebuttable presumption regarding such intention or knowledge that constitutes an element of the crime. Thus, with regard to crimes committed through the mass media, the Criminal Code provides that "[i]n determining the liability of a person ... for the crime committed through the product of mass media, the content of the matter shall be deemed to have been inserted, published or disseminated with ... full knowledge and consent" of the editor-in-chief, deputy editor, publisher, printer, disseminator, etc. ${ }^{161}$ [Emphasis added]. It is further provided that "[n]o proof to the contrary may be admitted in

${ }^{158}$ For further discussion on limitations on rights in the South African Bill of Rights see J. De Wall, I. Currie and G. Erasmus (2001) The Bill of Rights Handbook, Fourth Ed., (Lansdowne: Juta \& Co.) Chapter Seven, at $144 \mathrm{ff}$.

${ }^{159}$ In the UK system, as there is no written constitution; the parliament is supreme. Thus, such liberal restriction of rights by acts of the parliament cannot be unconstitutional. In systems where there is constitutional supremacy, such as ours, that is not the case. Every subsidiary legislation needs to conform with the formal and substantive requirements of the Constitution. Where there is legislation with a provision which is contrary to those constitutional provisions, certainly, those provisions of the subsidiary legislation would be of no effect.

160 Certainly, proving a state of mind is a difficult task for the prosecution. Confession is the best proof there is. Sometimes, confession is not even considered proof; it is considered as a waiver of proof rather than a proof. However, state of mind is also proved by circumstantial evidence; such relevant facts are motive, preparation for the commission of a crime, or premeditation.

${ }^{161}$ Crim. C., Art 43(5). Under this provision the fact that there was no knowledge and consent of the accused regarding the content inserted or disseminated is not defence; it would only be the absence of the content from such media outlet. 
such a case". ${ }^{162}$ These are not evidentiary provisions; they are substantive provisions which establish guilt by presumption because they preclude contrary proof. ${ }^{163}$ Such presumptions are contrary to the principles of presumption of innocence until proven guilty; the public prosecutor is excused from proving those facts that are deemed to exist. Such presumptions are also contrary to the constitutional "right to adduce or to have evidence produced in their own defence, and to obtain the attendance and examination of witnesses on their behalf before the court". 164

\subsubsection{Rebuttable presumption}

It is in the nature of the crime of corruption that state of mind should be proved separately as an essential element constituting the crime. Proof of the elements constituting the crime of corruption by presumption appears to be introduced by the Anti-Corruption Special Procedure and Rules of Evidence Proclamation No. 236/2001, Art 24. Such presumption is incorporated into the Criminal Code in broader form. Thus, there are presumptions regarding elements of crimes of corruption both for specific corruption offences as well as general/blanket presumptions for certain categories of corruption crimes.

\section{a) Presumptions regarding specific crimes}

Article 419(1) of the Criminal Code provides that a certain property is deemed to have been obtained by corrupt practices and such person is punishable where the public prosecutor proves that a person in a public office:

a) maintains a standard of living above that which is commensurate with the official income from his present or past employment or other means; or

b) is in control of pecuniary resources or property disproportionate to the official income from his present or past employment or other means ... unless he gives a satisfactory explanation to the Court as to how he was able to maintain such a standard of living or how such pecuniary resources or property came under his control.

There are also presumptions that affect persons that are related to the accused. It is provided that:

${ }^{162} \mathrm{Id}$.

163 A provision which is equivalent to the presumption of guilt is a stark contrast to the protection of freedom of expression enshrined in the Constitution. It is almost a presumption of guilt because the basic fact that is required to be proved is the mere content of the media product "inserted, published or disseminated."

${ }^{164}$ FDRE Const., Art 20(4). 
[where the Court] is satisfied that there is reason to believe that any person, owing to his closeness to the accused or other circumstances, was holding pecuniary resource or property in trust for or otherwise on behalf of the accused, such resources, or property shall, in the absence of evidence to the contrary, be presumed to have been under the control of the accused. ${ }^{165}$

These provisions establish and define the crime of corruption. In these provisions, presumptions of the facts constituting the crime are the bedrock of the crime of corruption. It is only by disproving these presumptions that a defendant may be acquitted from the charge of the crime of corruption.

\section{b) General/blanket presumptions}

The Criminal Code has introduced a general/blanket presumption of state of mind for those offences considered to be corruption. Thus, in any 'action' that is considered as a corrupt practice, the essential element of the crime, state of mind, is deemed to exist where other facts are proved. Article 360 of the Criminal Code provides that "[i]n respect of the crimes specified under Articles 356-359, the acts shall be presumed to have been done with the intent to utter." It is not clear whether this presumption is rebuttable or irrebuttable. However, it can be argued that because contrary proof is not expressly precluded and precluding such contrary proof would be contrary to the provisions of FDRE Const., Art 20(4), the right of defendant to present evidence in his defence, such presumption is rebuttable presumption. Another example of general or blanket presumption is embodied in Article 403 of the Criminal Code titled 'Presumption of Intent to Obtain Advantage or to Injure". The provision stipulates the following:

Unless evidence is produced to the contrary, where it is proved that the material element [the act] has been committed as defined in a particular Article providing for a crime of corruption perpetrated to obtain or procure undue advantage or to cause injury, such act shall be presumed to have been committed with intent to obtain for oneself or to procure for another an undue advantage or to injure the right or interest of a third person.

The provisions that follow Article 403 of the Criminal Code list the various categories of corruption offences. As is evident from the provisions, this presumption is rebuttable and the defendant may produce contrary evidence. However, disproving a presumed state of mind is more difficult than proving it. Thus, the burden on defendant is unreasonable.

${ }^{165}$ Id., Art 419(2) 


\subsubsection{The kind of presumptions contemplated in the Policy}

The Criminal Justice Administration Policy states that when certain basic facts are proved by the public prosecutor, the court shall presume the existence of certain other facts. It is, therefore, up to the defendant to disprove such presumption. ${ }^{166}$ This is also referred to in the various papers presented for implementation of the Policy. ${ }^{167}$ The presumption regarding the media is taken directly from the 1957 Penal Code, adopted four decades before the current Ethiopian Constitution, with minor modifications. The presumptions regarding the crimes of corruption are incorporated into the Criminal Code from Proclamation No 231/2001 without substantial modification, other than the minor change to give them a broader application for all crimes related to corruption. Therefore, it is hardly possible to expect a milder content or application of presumptions as contemplated by the Policy.

One might wonder whether the burden of proof contemplated to be shifted to the defendant is legal burden or evidential one. This question is legitimate in view of the words used in the papers presented for implementation of the Policy. As the papers are written in English they use the terms "reverse onus of proof". ${ }^{168}$ If we have to take the literal meaning of the terms, reversing the onus of proof is only shifting the evidential burden or the burden of production. It is hardly possible to take such terms literally and assume that they are used to mean what they actually connote. They are rather loosely used to mean shifting both the legal and evidential burden to defendant because, this distinction does not seem to be appreciated at all in the practice of various courts nor are defence counsels raising such arguments.

Therefore, such distinction, in Ethiopia's legal system, appears to be without effect. Further, even if it is understood and appreciated, there is no significant practical distinction between the legal and evidential burden. If a defendant is able to produce evidence it is only a little more effort to prove the facts operating in his favour. Therefore, the kind of presumption contemplated by the newly adopted Policy is not expected to be different from what is already in application - shifting both the legal and evidential burden to the defendant regarding the elements constituting a crime, usually intention or knowledge.

\footnotetext{
166 The Policy, Section 4.4.

167 There were about six papers for the implementation of the Criminal Justice Administration Policy. Only two of them are relevant to this subject where there is a specific mention of shifting the burden of proof to the defendant in few selected serious crimes: 1) Criminal Justice Administration Policy - Federal Democratic Republic of Ethiopia: Elements of an Implementation Plan, at 22; and 2) Preliminary Analysis of the Legislation Requirements of the Criminal Justice Administration 168 Policy, at 11; See supra note 72. Id.
} 
However, what cannot be stated for sure is whether the operation of the presumption will also be extended to other material facts or whether they will be limited to knowledge or intention.

\section{Burden of Proof in Alleged Coercion during Police Interrogation}

The police routinely interrogate suspects as part of the investigation process as per Article 27(2) of the Criminal Procedure Code. A major problem regarding burden of proof in criminal matters is that of proof relating to coercion during alleged confession of a defendant.

The interrogation of the defendant is not the main source of proof to establish crime. A case in point is trial in absentia. However, after having taught the law on criminal procedure and evidence for several years, this author has never encountered a court case which states that a defendant has opted not to give a statement to the police by exercising an accused person's constitutional right to remain silent. ${ }^{169}$ Stated otherwise, the suspect (the arrested person) always gives a written statement regarding the commission of the crime. In not few cases, the suspect confesses to the commission of the crime for various reasons. However, the public prosecutor produces the confession as the 'best' evidence on the matter. Often, the defendant contends that he had confessed to the crime on coercion and it should not be admissible as evidence against him.

In the ideal scenario, as laying the foundation of the evidence, the public prosecutor has to prove that such confession is obtained in conformity with the Constitution. In such cases, however, the courts wrongly shift the burden of proof to the accused. The usual erroneous judicial reasoning is that because the defendant asserts the affirmative about police misconduct during investigation, he has to prove his assertion. In some cases, the confession is relevant not only for its content but also for other evidence gathered based on the confession, commonly referred to as fruits of a poisonous tree. Unfortunately, the burden of proof in alleged confession cases is convoluted with other unrelated matters. This is particularly so when courts fail to properly frame the issue.

In police misconduct cases, the defendant challenges propriety by contending that the evidence is unlawfully obtained thereby submitting that it should not be admitted into evidence. The courts on the other hand, frame the issue from the

169 The accused appearing before the investigating police officer (whether on summons or by a compulsory process) may deny or admit the commission of the crime. The third possibility can be opting to keep silent. The author has not seen a police investigation report submitted to the public prosecutor stating that the suspect is present and he, exercising his constitutional right, has refused to give statements. 
perspective of veracity and, in effect, proceed to examine whether such confession is reliable evidence in the matter. ${ }^{170}$ Thus, even in cases where defendant proves coercion, such courts often reason that, the confession is supported by and is in conformity with other evidence and is therefore reliable. $^{171}$

The issue in the alleged confession case is whether such confession is obtained lawfully. In view of the above test for allocation of the burden of proof, it is the public prosecutor who has the burden of proving that the confession was obtained lawfully. That is because the public prosecutor is asserting the affirmative and thus has to prove that the confession is obtained in conformity with the Constitution and other provisions of the law. ${ }^{172}$

In whatever form the confession of a defendant is presented to a court, it is usually presented as documentary evidence. It is, however, arguable whether it is documentary evidence. The public prosecutor submits it to court under the expectation that it is obtained in accordance with the law, and this constitutes its foundation. For the defendant, however, it is good enough if he states that the confession is obtained contrary to law. Such is the case when a person disclaims

${ }^{170}$ In Federal Ethics and Anti-Corruption Commission v. Tamirat Layine, et al., defendant alleged that he gave incriminating statements to the police after he has been psychologically coerced by the latter. The Federal Supreme Court held that "the confession is supported by other evidence and it cannot be said unreliable." (Federal Supreme Court, 2000, Crim. F. No. 1/89). In Tesfaye Engdayehu v. Public Prosecutor, defendant proved he was tortured by the police. The court, however, held that his confessions are consistent with other evidence and are thus reliable (Supreme Court Circuit Bench, Cr. App. File No. 162/Wollo/74). Likewise, in Ali Dugadibo v. Public Prosecutor defendant claimed police misconduct (Supreme Court Circuit Bench, Cr. App. File No. 171/75). The court framed almost the same issue and arrived at the same conclusion as above. However, the court acquitted defendant not because of the proof of allegation of police misconduct but because the confession is the only evidence and there is a contradiction between the confession given to the police during investigation and the confession given to the Woreda Court at the preliminary inquiry.

Id.

172 Before a documentary evidence or a real evidence is admitted, it must be proved that the evidence is what it is purported to be. This is what is called laying the foundation. Park, et. al., supra note 75, at $501 \mathrm{ff}$. Laying the foundation, however, has a wider application than authentication. For instance, before a secondary evidence is admitted, the proponent must prove the primary evidence is lost (E.g., Civ. C., Art. 2003). Authentication and laying the foundation are preconditions to the admissibility of an item of evidence. G. Weissenberger, Federal Evidence: 1996 Courtroom Manual (Cincinnati: Anderson Publishing Co.), at 244; also see FRE rule 901 Requirement of Authentication or Identification. 
his alleged handwriting or signature in a non-authenticated document (Civ. C., Art 2007(1)) or where heirs "declare that they do not recognize the writing or signature of their ascendant" who is deceased. (Civ. C., Art 2007(2)). Likewise, Section 104 of the Indian Evidence Act provides that "[t]he burden of proving any fact necessary to be proved in order to enable any person to give evidence of any other fact is on the person who wishes to give such evidence."

There are also other reasons why the public prosecutor has the burden of proof of propriety in confession cases. First, the public prosecutor has a constitutional duty to see to it that the rights of the suspect under Chapter Three of the Constitution are respected and enforced. ${ }^{173}$ Among various fundamental rights, the suspect is entitled to the protection against any form of cruel, inhuman and degrading treatment ${ }^{174}$ and the presumption of innocence. ${ }^{175}$ Thus, when the public prosecutor presents the alleged confession as evidence against the defendant, he is also asserting the affirmative that, the confession is obtained respecting the constitutional rights of the suspect/accused and that the public prosecutor has discharged its constitutional duties to enforce and protect those rights.

Second, a distinction should be made between statements made to the police (under Article 27(2) of the Criminal Procedure Code) as extra-judicial admissions or evidential admissions ${ }^{176}$ and the judicial admissions that are made before the court (based on Articles 35, 132, etc of the Criminal Procedure Code). As the court judicially notices the fact of making the latter admissions and their contents, judicial admissions need not be proved. Extra-judicial admissions are, on the other hand, made outside the court, to whomever they are made. In such instances, the facts stated in such confession and their content must be proved to the court. ${ }^{177}$ One such confession is the one made to the police based on Crim. P. C., Art 27(2). This is called laying the foundation before evidence is admitted.

Furthermore, it is the state that chooses the place, time and setting for investigation and interrogation. Defendant has very little choice, if any, during interrogation. It is difficult, if not impossible, for a defendant to prove that he was coerced while being interrogated by the police. Where the state makes it

${ }^{173}$ FDRE Const., Art 13(1).

174 Art 18.

175 Art 20(3).

176 Giannelli, supra note 139 , at 434, 435.

177 There are two aspects of challenge to extra-judicial admissions: the hearsay aspect and the constitutionality aspect. What is relevant here is the constitutionality aspect of the challenge. 
difficult for the individual to prove propriety during confession, then it is on the public prosecutor to prove that the confession is obtained lawfully. ${ }^{178}$

\section{Concluding Remarks}

There are several manifestations of the rights of a person to be presumed innocent until proven guilty. One such manifestation is the duty of the public prosecutor to prove all the elements constituting the crime beyond a reasonable doubt. The defendant on the other hand, does not have to participate in the proof against him. There are, however, several ways by which the principle of presumption of innocence is violated in our criminal justice administration. First, there are provisions in the Criminal Code that establish the existence of an element of the crime, including intention/knowledge by presumption. When such presumption is rebuttable presumption, both the evidential and the legal burdens are shifted to the defendant in violation of the constitutional principle of the presumption of innocence and the notion of fundamental fairness in the administration of the criminal justice. And where the presumption is irrebuttable, it entirely nullifies the constitutional right of the accused to present evidence in his defence.

The newly adopted Criminal Justice Administration Policy contemplates shifting the burden of proof to the defendant in few serious crimes, such as, crimes against the constitution and the constitutional order, terrorism and organised crime. The nature of the presumption and the elements of the crime that can be proved by presumption are yet to be defined by the law. While the government, with all the resources and specialized justice institutions, is said to have found it difficult to prove the elements that constitute such crimes, it is clearly unfair to expect a defendant to be able to effectively submit his defence once such element is presumed to exist. Moreover, it is a consistent practice that when a defendant challenges the admissibility of the confessions obtained during interrogation because of police misconduct, the courts require him to prove coercion.

The presumptions in the Criminal Code operate in several crimes each of which constitutes and element of a serious offence. The crimes wherein proof by presumption is contemplated in the Criminal Justice Administration Policy are more serious and entail severe penalties. The fact that these crimes are mostly non-bailable and severely punished should have been taken as a deterrent not to use presumptions as proof in such matters. The additional predicament relates to

${ }^{178}$ This argument on difficulty of proof of facts cuts two ways - both for and against defendant. However, the difficulty of proving coercion emanates from the state's choice of the place, time and manner of interrogation. The individual suspect does not choose where to be interrogated. 
the lack of physical freedom of the defendant in order to gather evidence under a setting whereby the Public Defender's Office is almost non-existent. Even if courts may grant a defendant the opportunity for movement in order to obtain evidence and to contact witnesses, such permission by the court is not even as half effective as being released on bail to defend oneself. Such laws, policy and practices clearly nullify the principle of presumption of innocence enshrined in the Ethiopian Constitution and its constitutional values. 